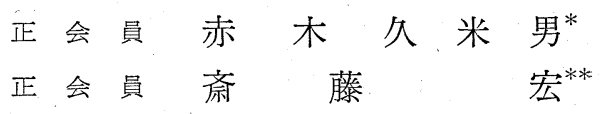

\title{
On the Influence of Coal Dust upon Spark Discharge
}

Kumeo AKAKI and Hiroshi SAITO

Various fundamental experiments were carried out on the influence of coal dust upon spark discharge, and the experiments were performed under conditions as similar as possible to those in coal mines. The results obtained were as follows:

(1) When coal dust is dropped on the electrode in a glass vessel, corona current increases and spark voltage decreases. The smaller the sizes of coal particles are, and the larger the quantity of the dropped coal dust is, the greater the effect will be.

(2) When DC voltage is impressed at the needle to plate electrode, the effect of polarity is remarkable, and this is considered to have certain bearings with the attached quantity of coal dust.

(3) When compared with other dusts, coal dust is observed to be particularly influential on spark discharge.

(4) On the influence upon surface discharge, of accumulated coal dust placed on the insulating plate: coal dust in small quantity makes electric current increase and makes the break-down voltage along the plate surface decrease, but as the quantity of coal dust increases, the current decreases, and the voltage increases.

(5) On the relation between the accumulated quantity of coal dust and the breake-down voltage along the plate surface: the break-down voltage shows the maximum value at a certain point of accumulated quantity of coal dust, and when the quantity is over that point, the voltage becomes decreased.

\section{1. 緒言}

炭鉱内の電気施設においてもつとも問題になるのは， その施設の火花放電等に基うくく誘導ガス炭じん爆発であ る。一般に炭坑内は湿度80 98\%の高湿度でしかも相当 の浮遊炭じんがあり，炭じんの発生状態の時間的変化は 著しいことが報告されている。

著者らは炭坑内のなるべく実際に近い状態のもとで， 炭じんが放電にいかなる影響をおよぼすかを調べるため 種々基整的実験を試みたところ, 浮遊炭じんは一般にコ ロナ電流を増加し，火花電圧を低下させ，その影響が他 の粉体よりも特に著しいこ之がわかつた。また堆積炭じ んの沿面放電におよぼす影響についても実験を行なつ た。これらの実験は研究途上のものもあるが一応これま での実験結果を報告する。

\section{2. 浮遊炭じんの気中放電におよばす影響12233)9}

\section{$2 \cdot 1$ 実験方法}

実験装置 ${ }^{4}$.を第 1 図に示す。この装置において, 炭じ

*昭和 42 年 9 月 16 日受理

***秋田大学教授 鉱山学部電気工学科

*****秋田大学講師鉱山学部電気工学科

ん試料をふるいC上にのせ, 電動機 $\mathrm{M}$ 回転させ振動棒 Bによりふるいに上下振動を与光, 容器 X内に一様に炭 じんを落下させる。このようにして均一な炭じん雲を作 り, 電極 $\mathrm{G}$ に直流電圧 (片側接地) を印加し各特性の測 定を行なつた。この装置において電動機の回転数, 振動 棒の腕の長さ, ゴムの張力, ふるいの目の大きさを加減 することにより粒度の異なつた各炭じん試料について希 望の濃度の炭じん雲が得られ, かつ実験の再現性におい ても信頼度の高い結果が得られた。電極としては, 先端 を半球状に仕上げ先端曲率半径を $0.3 \mathrm{~mm}$ としたぬい針 と面積 $7.07 \mathrm{~cm}^{2}$ の真ちゅら製平板を用いた。炭じん試料

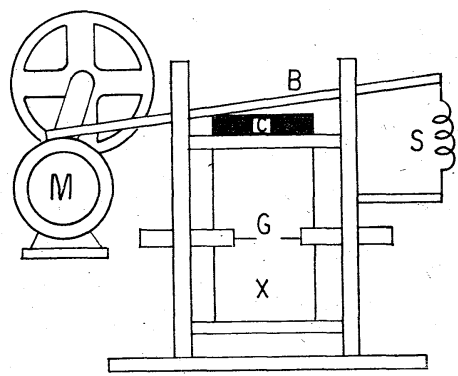

第1図 炭じん降下装置

\section{$\mathrm{M}:$ 小型モーター B : ふるい振動棒 $\mathrm{C}:$ 標準ふるい \\ G : 電 極 $\mathrm{X}:$ ガラス製円筒 実験槽 $4106.5 \mathrm{~m} \ell$ 底面積 $191 \mathrm{~cm}^{2}$}

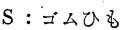

Vol. 84 No. 958 ('68-2) 


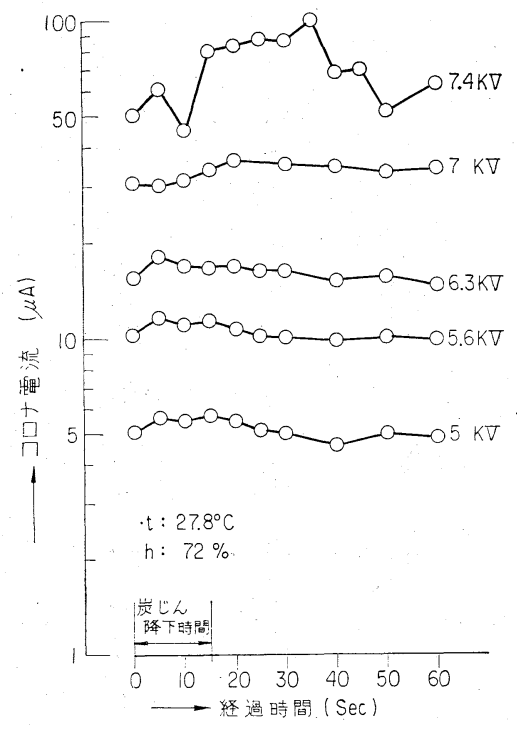

第2図コロナ電流への炭じんの影響

注各種粒度のものをデシケータに入れ充分乾燥させて実 験に使用した。

\section{$2 \cdot 2$ コロナ電流への影響}

第 1 図の装置の電極間に一定電圧を印加しておき，炭 じんを降下させた場合のコロナ電流を測定した。その一 例を第 2 図に示す。これは針 $(-)$ 対針 $(+)$ 接地の電

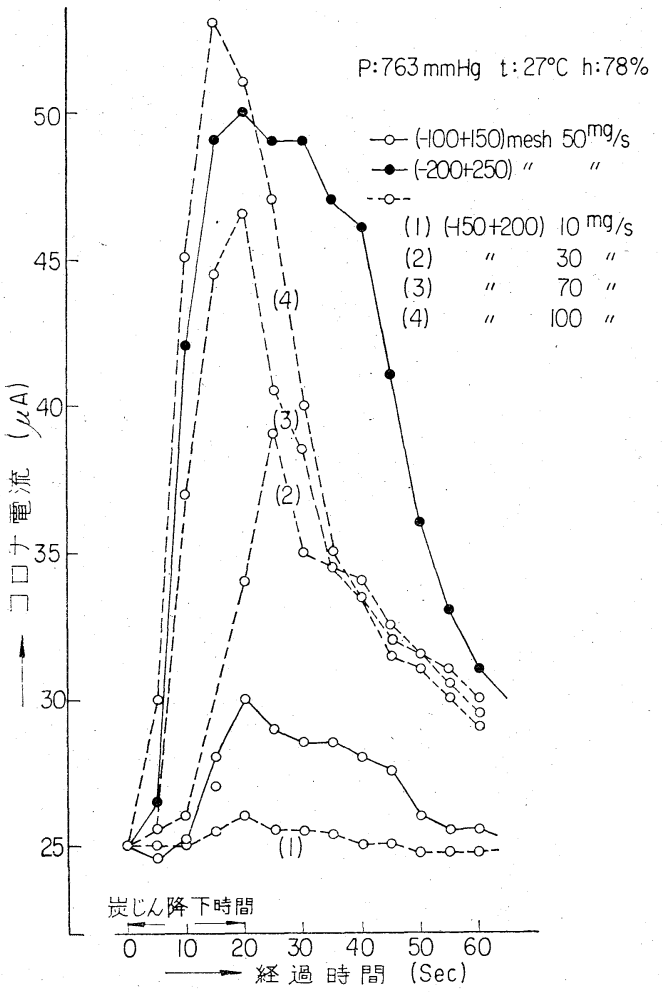

第3図孷じん降下量と粒子別のコロナ電流への影響
極間（電極間距離 $10 \mathrm{~mm}$ ）に $80 \mathrm{mg} / \mathrm{s}$ （容器底面上での 降下量 / 単位時間) の割合で $-100+150$ mesh の炭じん を15秒間降下させ，1分間コロナ電流を測定したもので ある。一般に炭じん降下によりコロナ電流は増加する。 しかも，印加電庄を上昇させる（すなわち最初に設定す るコロナ電流を増す）にしたがい炭じん降下の影響が著 しく, 7. $4 \mathrm{kV}$ 印加時 (設定電流 $50 \mu \mathrm{A}$ ) においては, コ 口ナ電流は $100 \mu \mathrm{A}$ にも達し, 大気中のコロナ電流より も $50 \mu \mathrm{A}$ も増加する。また大体 $30 \mu \mathrm{A}$ 以上の線条コ口 ナでは炭じんの降下によりコロナ電流が一度隇少してか ら増加する現象が認められた。

次に炭じん粒子の大きさおよび降下量による影響を第 3 図に示す。これは針 $(-)$ 対平板 $(+)$ 接地電極（電極 間距離 $10 \mathrm{~mm})$ で一定のコロナ電流 $(25 \mu \mathrm{A})$ のもとで, 炭じん粒度と降下炭じん量を変えて, 炭じんを20秒間降 下して，コロナ電流を測定したものである。この図にお いて，実線は降下炭じん量を一定 $(50 \mathrm{mg} / \mathrm{s})$ とし炭じん 粒度を変えて比較したものであり, 点線は同一粒度 (一 150+200mesh)で降下量を変えた場合である。図に見る ごとく炭じん粒子が小さいほど，また降下量が増すほど 影響が大である。なお極性を反対にした，すなわち針 (十) 対平板 (一) 接地の場合は炭じんの影響が比較的少 なく, ある場合には炭じん降下によつてコロナ電流が減 少する反対の現象も見られた。

\section{$2 \cdot 3$ 火花電圧におよぼす影響}

炭じんが火花電圧におよぼす影響を見るため，種々の

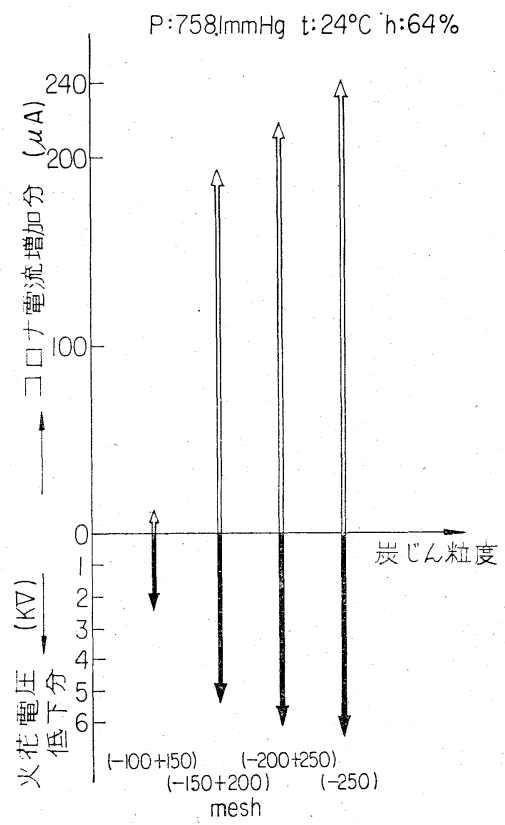

第4図 炭じん粒子別によるコロナ電流の 增加と火花電压の低下 
$P: 759 \mathrm{mmHg} t: 22.5^{\circ} \mathrm{C} \mathrm{h:73 \%}$

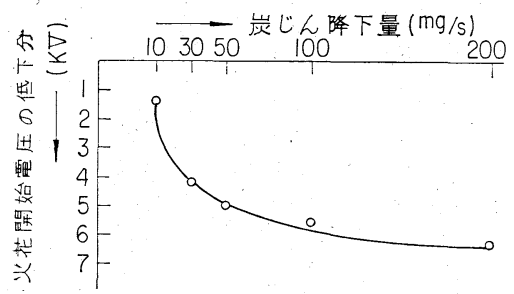

第 5 図 降下炭じん量と火花電圧の低下

炭じん粒度，降下量に対する火花電圧を測定した。すな わち, 大気中の火花電圧より低い電圧を電極間に印加し ておき，これに炭じんを降下させるとコロナ電流が急増 して火花放電となる。次にさらに低い電圧を設定して炭 ビんを降下させて火花放電を生ずるかを見る。このよう にして設定電圧を次第に低くして，炭じんの降下によ り，50\%放電率で火花放電が発生する火花開始電圧を求 めた。第 4 図は針 $(-)$ 対平板 $(+)$ 接地電極（電極間距 離 $8 \mathrm{~mm}$ ) で $50 \mathrm{mg} / \mathrm{s}$ の炭じん降下量のもとで炭じん粒 度を変えた場合，火花開始電圧およびその時のコロナ電 流が同じ条件下の大気中火花電圧 $(13.2 \mathrm{kV})$ およびコ口 ナ電流 $(228 \mu \mathrm{A})$ よりいかに増減したかを示したもので ある。困に見るごとく最小粒度 $-250 \mathrm{mesh}$ 降下の場合 には，6.7kV，467 $\mu \mathrm{A}$ で火花放電となり，すなわち 6.5 $\mathrm{kV}$ の電圧低下， $239 \mu \mathrm{A}$ の電流増加を示している。第 5 図は第 4 図と同じ電極配置 (電極間距離 $8 \mathrm{~mm}$ ) でー150 +200mesh炭じんの降下量を変化させた場合の火花開始 電圧の低下を第 4 図と同じく大気中火花電圧と比較した ものである。

第 4 図および第 5 図からわかるよらに，火花電圧にお よぼす影響も炭じん粒子が小さいほど，また降下量が増 すほど影響が大である。ところが極性を反対にした針 (十) 対平板 (一) 接地電極では，わずかながら火花電圧 が上昇する場合もあつた。すなわち，-150+200mesh 炭じんを $50 \mathrm{mg} / \mathrm{s}$ の割合で降下させた場合，火花電圧が $0.8 \mathrm{kV}$ 上昇し，その時のコロナ電流は $5 \mu \mathrm{A}$ 減少した。

\section{$2 \cdot 4$ 両電極への炭じん付着}

針対平板電極で炭じん降下の実験中，降下炭じん量の

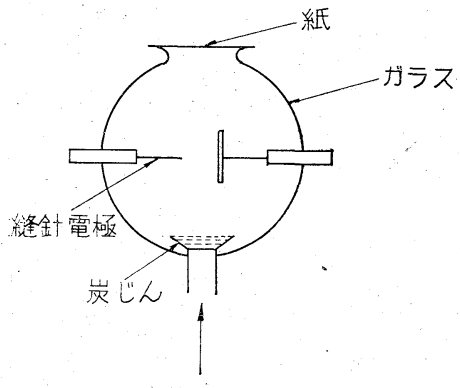

第6 図 ガラス容器と 電極

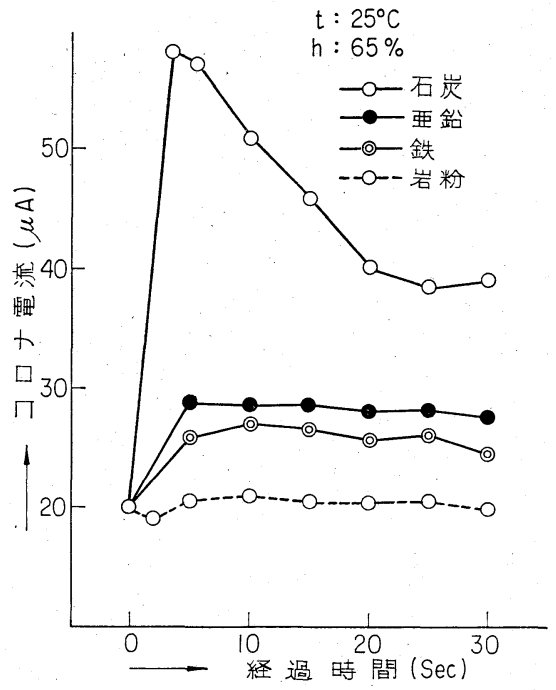

第7図 各種粉体がコロナ電流に及ぼす影響

約 $5 \%$ が両電極に付着する。その付着の割合は大体高圧 側 (+) 1 亿対し接地側 (-) 2 ，高圧側 (-) 1 に対して 接地側 (十) 4 ぐらいであつた。接地側平板 $(+)$ のとき は平板電極一面に厚く付着するが，平板 $(-)$ のきはド 一ナツ形に薄く付着した。次に，幅 $5 \mathrm{~mm}$ ，厚さ $0.5 \mathrm{~mm}$ の銅製平板電極を両極同形として，電極間に $6 \mathrm{kV（コロ}$ ナ電流 $10 \mu \mathrm{A})$ を印加し, -250 mesh 炭しん $3 \mathrm{~cm}^{3}$ を電極 下 $10 \mathrm{~cm}$ より $200 \mathrm{~g} / \mathrm{cm}^{2}$ の圧力で吹き付けたところ, 高 圧側, 接地側に関係なく吹き付け量の約 $3 \%$ が陽極に, 約 $1 \%$ が陰極に付着した。これらの現象は炭じんの種 類，炭じんの新旧すなわち酸化の程度，あるいは実験装 置の材料によつて多少異なるようであるが，一般に浮遊 炭じんはコロナによつて負に帯電される粒子の方が非常 に多いことがわかる。前述の炭じん降下がコロナ電流や 火花電圧におよぼす影響や，極性によつて反対になる現 象は，この両電極への炭じんの付着の差異が大いに関係 しているものと考えられる。

\section{5 他の粉体との比較}

炭しん以外の粉体は放電にどの程度の影響を与えるか を測定，比較した。ただし，各粉体は比重が非常に異な るため，重量を一定にして比較するよりも容積を一定に して比較する方が妥当であると考え，第 6 図のようなガ ラス容器内にぬい針（先端曲率半径 $0.3 \mathrm{~mm}$ ） と真ちゆ ら製平板 (面積 $7.07 \mathrm{~cm}^{2}$ ) を電極とし直流電圧を印加し, 電極下 $10 \mathrm{~cm}$ より $200 \mathrm{~g} / \mathrm{cm}^{2}$ の圧力で $1 \mathrm{~cm}^{3}$ の各種粉 体を吹き付け各特性を測定した*。吹き付け後約 5 秒で 容器内は浮遊粉体で一杯となるが, 約 30 秒後には大体浮

*この装置を用いての炭じんの気中放電に特よばす影響（コロナ電

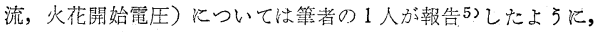
前述の第 1 図の装置を用い炭じんを降下させて測定した結果と注 淕同じ傾向を示している。 
遊粉体は沈降する。使用した粉体 $(-200+250 \mathrm{mesh}) 1$ $\mathrm{cm}^{3}$ あたりの重さを比較すると，温度 $25^{\circ} \mathrm{C}$, 湿度 $65 \%$ の室内で炭じん $: 0.6 \mathrm{~g}$, 岩粉 $: 0.9 \mathrm{~g}$, カーボランダム $: 1.1 \mathrm{~g}$ ，亜鉊： $1.6 \mathrm{~g}$, 鉄 $: 1.7 \mathrm{~g}$ であつた。

第 7 図は針 $(-)$ 対平板 $(+)$ 接地電極（電極間距離 10 $\mathrm{mm}$ ) に直流電圧を印加し，コロナ電流を $20 \mu \mathrm{A}$ に設定 して, $-200+250$ mesh の各種粉体を吹き付けて 30 秒間 コロナ電流の変化を測定した一例である。図に見るごと く炭じんの影響が最大で岩粉および金属粉の影響は比較 的小である。

その他火花電圧におよぼす影響も粉体によりそれぞれ 異なり, 炭じん以外の粉体については改めて報告するつ もりであるが，炭じんは他の粉体と異なる影響を放電に およぼすようである。

\section{3. 堆積炭じんの沿面放電におよぼす影響6)99}

\section{$3 \cdot 1$ 電圧一電流特性}

堆積炭じんが沿面放電におよ汸す影響を調べるため, 第 8 図のように絶縁板上にアルミニウム簿 $(0.02 \mathrm{~mm}$ 厚 さ）をはりつけ電極としたものと第 9 図のようにぬい針 を電極としたものを作り，その上に炭じんを 堆積して直流電圧 (一側接地) を印加し, 電 圧一電流特性を求剠。第 10 図は絶縁板と してガラス板にゼラチン膜面を付けて充分に 乾燥したものを使用し，アルミニウム簿電極 の電極間距離 $10 \mathrm{~mm}$ および $13.4 \mathrm{~mm}$ の場合 の比較的高湿度中のゼラチン膜面上沿面放電

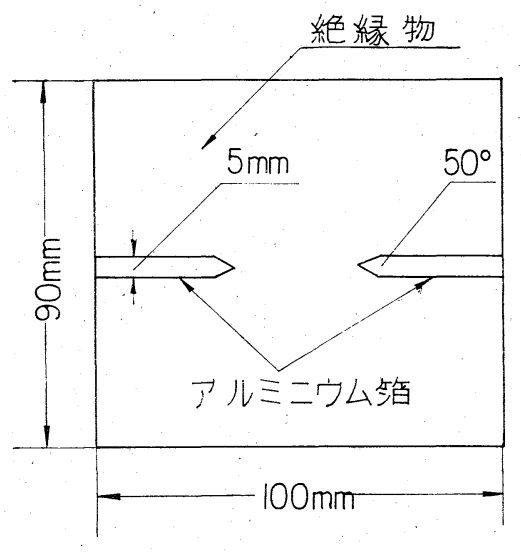

第8図

絶縁板上アル ミニゥム電極

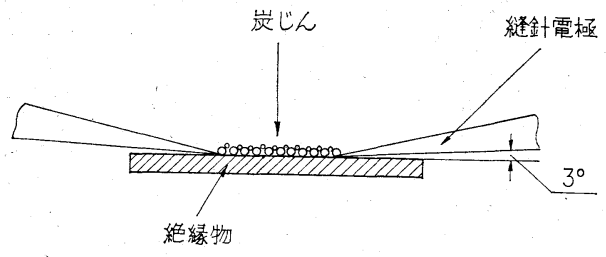

第 9 図絶縁板上と縫針電極
と,この絶縁板上に $-100 \mathrm{mesh}$ 炭じんを $15 \mathrm{mg} / \mathrm{cm}^{2}$ の せた場合の電圧一電流特性を比較したものである。一般 にこの程度の堆積炭じん量では, 大気中のゼラチン膜面 上沿面放電よりも膜面上に堆積炭じんのある場合の方が 同一電圧に対して電流は大となり，沿面破壊電圧は高く なる。

次に絶縁板 (ガラス板) 上にぬい針を電極（電極間距 離 $10 \mathrm{~mm}$ ) とし, 分ラス板上の $-200+250 \mathrm{mesh}$ の堆積炭 じん量を変え, 直流電圧 (一側接地) を印加し電圧一電 流特性を測定したものを第11図に示す。この図において 堆積炭じん量 $5 \mathrm{mg} / \mathrm{cm}^{2}$ の曲線 I は炭じんの無い場合の 曲線IVより常に電流が増大し, 火花電圧はわずかに低下 する。炭じん量 $10 \mathrm{mg} / \mathrm{cm}^{2}$ の曲線 II では, ある電圧值ま では炭じんの無い場合よりも電流が多いが，それ以上の 電圧では曲線 IV と反詨位置になり火花電圧は高くなる。 炭じん量 $50 \mathrm{mg} / \mathrm{cm}^{2}$ の曲線而では電流が非常に小さく火 花電圧は一層高くなつている。すなわち堆積炭じん中の 沿面放電では少量の炭じんは電流を増し, 火花電圧を低 下させるが, 炭じん堆積量が増すにしたがい電流が減少 し，火花電圧を高くする。

(I) $t: 155^{\circ} \mathrm{C} \quad h: 86 \% \mathrm{~d}: 10 \mathrm{~mm}$ 堆積炭じんなし

（II）同上 -100 mesh 堆積炭じん $15 \mathrm{mg} / \mathrm{cm}^{2}$

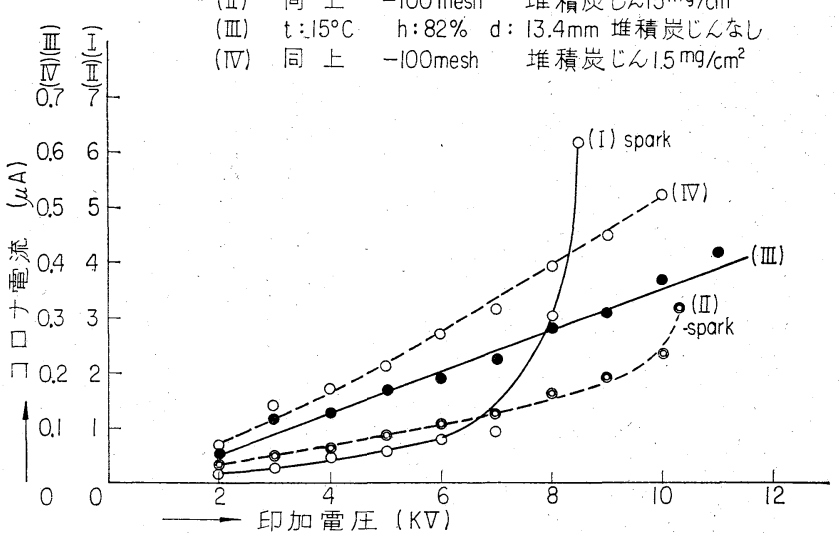

第10図 ゼラチン膜面上沿面放電に括けるV-I 特性

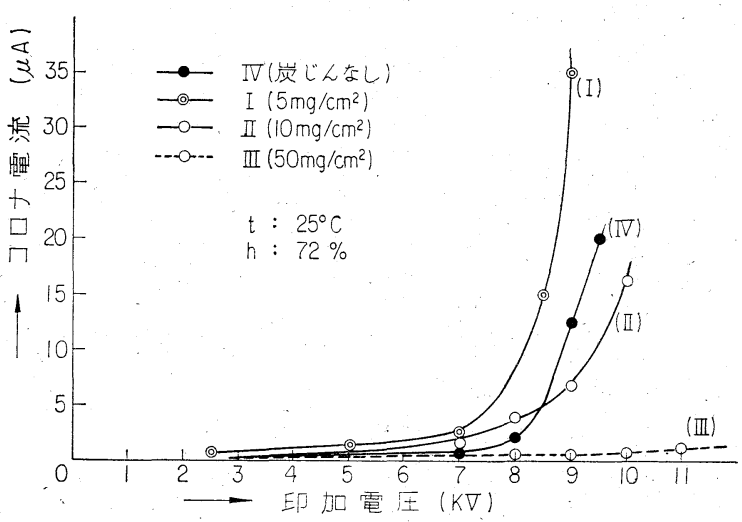

第11図 堆積炭じん量別によるV-I 特性 
なおこのような実験結果はエボナイト板, ポリエス チロール板のような表面漏れ抵抗の大きい絶縁板上で も，電流は小さいが同様の傾向が見られた。また炭じん 粒度が小さいほど，この影響は著しく，60mesh 以上の 大きな粒子では影響が少なくなる。

\section{$3 \cdot 2$ 炭じん堆積量と沿面破壊電圧}

炭じん堆積量の沿面破壊電圧への影響を調べるため, 第 8 図の絶縁板上のアルミニウム䇴を電極とし, 衝撃電 圧, $50 \mathrm{c} / \mathrm{s}$ 交番電圧, 直流電圧 (十側接地) を印加し, 電極間距離を変えて堆積炭じん量に対する沿面破壊電圧 の変化を測定した。第12眓は乾燥させたゼラチン膜面上 のアルミニウム箔電極に衝撃電圧（標準衝撃電圧波形を 印加した場合の -100 mesh 炭じんの堆積量と火花電庄 との関係を示した曲線である。眓からわかるよらに，堆 積炭じん量が増すにしたがい火花電庄が上昇し，堆積炭 ごん量約 $60 \mathrm{mg} / \mathrm{cm}^{2}$ 付近にて最大となり，それ以上炭じ 几量が増すと反対に火花電庄が下降するが，最初の炭じ んの無い沿面放電の場合より以下には低下しない。これ の放電状況を観察すると, 火花が飛ぶ場合汇絶縁板上の

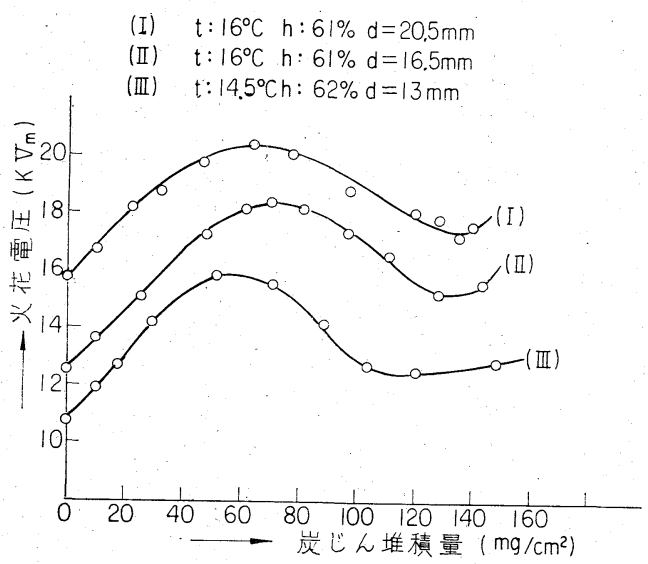

第12図 衝撃電圧印加による炭じん堆積量と火花電圧

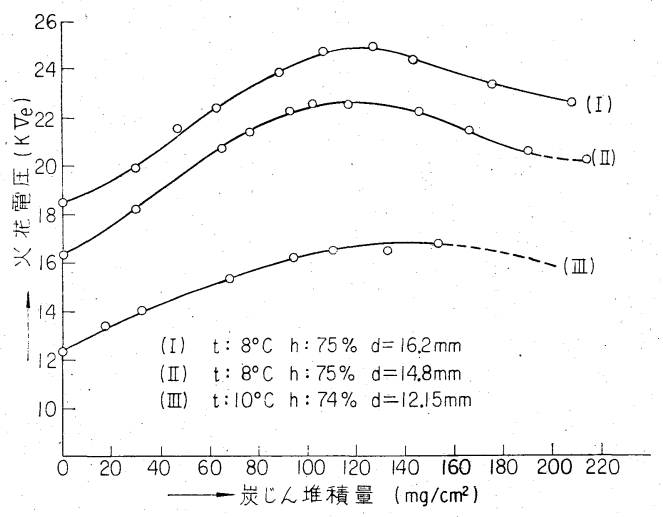

第13図 交番電圧印加による炭じん堆積量と火花電圧

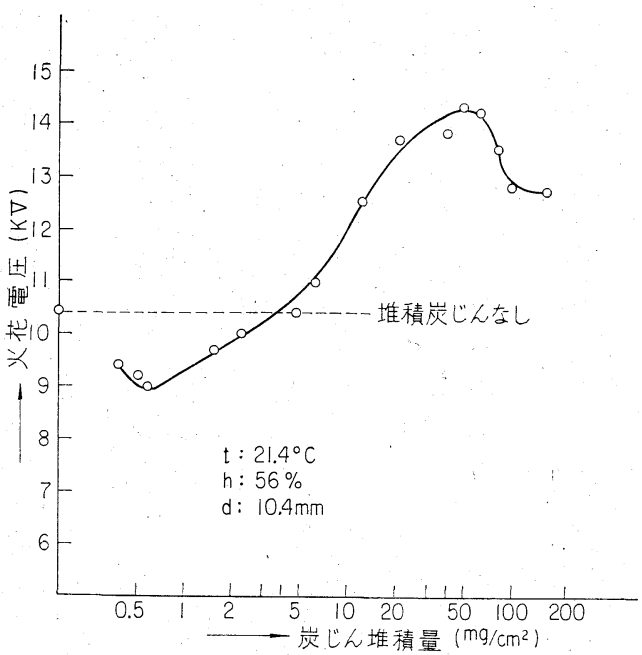

第14図 直流電圧印加による炭じん堆積量と火花電圧

炭じんをは放とばすが，火花電圧の最高点を越すと炭じ ん量が増すにしたがい放電路が次第に炭じん中に没して 見えなくなり， $120 \mathrm{mg} / \mathrm{cm}^{2}$ 以上では両電極上に小孔が 見えるだけで放電路は炭じん下にトンネルの形式とな る。第13図は衝撃電圧印加の前図と同じく乾燥させたゼ ラチン膜面上のアルミニウム䈃電極に $50 \mathrm{c} / \mathrm{s}$ 交番電圧を 印加した場合の，少こし粒度の大きいものを含む -65 mesh 炭じんの堆積量と火花電圧の関係を示す。この場 合には火花電圧が最大となる位置が堆積炭じんの量の増 す方に移動している。次に第14図は絶縁板としてべーク ライト板を使用し, 粒子の小さい $-200+250 \mathrm{mesh}$ の堆 積炭じん量を変化させ, 直流電圧 (十側接地) を印加 し，火花電圧を測定したものである（ただし，堆積炭じ 几量が少量の場合飞火花電圧が低下する領域を拡大する ため堆積炭じん量の横軸を対数目盛で示してある。)。図 に見るように， $0.6 \mathrm{mg} / \mathrm{cm}^{2}$ 付近で火花電圧が最低とな り, 約 $5 \mathrm{mg} / \mathrm{cm}^{2}$ 以上から炭じんの無い場合より火花電 圧が高くなつている。直流電圧印加の場合は, 極性を変 えても堆積炭じん量と火花電圧の関係は同じ傾向を有し ている。

以上 3 種類の実験においては堆積炭じん量の変化によ る沿面破壊電圧曲線は同様の傾向があり, ある堆積炭じ ん量において火花電圧の最大点があり，その点を越すと 炭じん量の増加にしたがい火花電圧は下降するが，炭じ んの無い場合の火花電圧よりは低下しない。この傾向は 絶縁板, 電極間距離を変えても, また電極形状を変えて も?，同様である。

電極間に電圧を印加した場合，コロナ風あるいは炭じ ん粒子の帯電等により, 炭じん粘子は運動する。特に， 堆積炭じえ量が少量の場合にはこの炭じん粒子の運動が 活発となり，2.に述べた炭じんを降下させた場合と同様 
火花電圧は低下する。ところが堆積炭じん量が増すにし たがつて，炭じん粒子の運動が制限され，筆者の一人が 理論的に検討 ${ }^{8)}$ した放電通路の延長などにより火花電玨 が高くなるものと考它れる。

\section{4. 結言}

放電におよぼす炭じんの影響についての一連の実験の 結果，次のことが明らかとなつた。

（a）浮遊炭じんの放電におよぼす影響

i）浮遊炭じんはコロナ電流を増加させ, 火花開始 電圧を低下させる。その影響は炭じん量が増すほど，炭 ビん粒子が小さいほど大である。

ii）針対針電極に㧍ける直流印加の場合には，極性 の影響はあまり見られないが,針対平板電極においては， 極性の影響が著しい。すなわち，針 $(-)$ 対平板 $(+)$ 接地 電極においては, コロナ電流増加および火花電圧の低下 の現象が甚だしい。これに対して，針 $(+)$ 対平板 $(-)$ 接 地電極に㧊いては，上記現象と反対の現象すなわちコロ ナ電流の減少，火花電圧の上昇を見る場合もある。

iii）上記の実験において，炭じんが両電極に付着す るが特に $(+)$ 極に比較的多く付着する。これはコロナに より(一)に带電する炭じん粓子が多いための現象と考兄 られる。上記の極性による影響法この両電極への炭じん の付着の差異が大い関係しているむのと思われる。

iv）他の粉体との比較の結果, 放電に抢よぼす影響 は炭じんが，特に著しい。

（b）堆積炭じんの沿面放電におよぼす影響

i ）堆積炭じん量が少量 ( $5 \mathrm{mg} / \mathrm{cm}^{2}$ 以下)の場合は 炭じん粒子の運動により, 気中放電の場合と同様, 炭じ んの無い場合よりもコロナ電流を増加し，火花電圧を低
下させる。

ii）それよりも堆積炭じん量を増して $15 \mathrm{mg} / \mathrm{cm}^{2}$ 位 まではコロナ電流は増加するが, 火花電圧は炭じんが無 い場合よりも高くなる。

iii）堆積炭じん量一沿面破壊電圧曲線において, あ る堆積炭じん量にて破壊電圧の最大点があり, その点を 越すと破壊電圧值は下降する。しかし, 堆積炭じんの無 い場合以下には低下しない。これらは放電のPath 等に 関係するむのと考えられる。

上記の実験の結果より,電気機器の絶縁設計の際には, 浮遊炭じんのある場合および少量の堆積炭じんのある場 合には火花電圧が低下するといらことを充分考慮する必 要があるものと考劣られる。

終りに実験に協力していただいた本学部加賀昭夫助 手, 松井清技官ならびに元学生小野詞郎, 半田勇の諸氏 に感謝の意を表する。

\section{参 考 文 献}

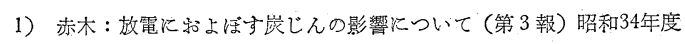
電気関係学会東北支部連合大会

2）赤木・紊藤：粉体が放電汇特よぼす影響, 昭和 37 年度電気関係学会 東北支部連合大会

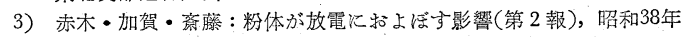
度電気関係学会東北支部連合大会

4) 石浜・岡田・吉田・関本：炭じん爆発関する研究(その1) 資源 技術試験所北海道支所報告

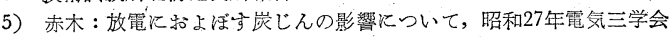
東京支部連合大会

6）赤木：沿面放電に及济す堆積炭じんの影響, 昭和 26 年度電氮関傒学 会東北支部連合大会

7）赤木・半田：沿面放電に及湾す堆積炭じんの影響(第 2 報)、昭和 30 年度䉓気関係学会東北支部連合六会

8）赤木：炭坑内に和的る火花放䉓の研究, 秋田大学釷山学部地下資源 開発研究所報告 No. 6 (1951)

9）赤木 : 炭坑内江和㚈る火花放電特性, 第 8 回東北鉱山学会 (1951) 